\title{
E-Learning Readiness in Organizations
}

\author{
Case KBC Bank \\ http://dx.doi.org/10.3991/ijac.v5i1.1885 \\ Jeanne Schreurs and Ahmad Al-Huneidi \\ Hasselt University, Diepenbeek, Belgium
}

\begin{abstract}
Many organizations failed in adopting e-learning. A primary reason for this failure is the lack of assessment of organizational readiness for e-learning. To reduce failure risk, organizations should assess their readiness for adopting e-learning to identify some weak points which have to be improved by taking some improvement actions. In the literature we can find a variety of e-learning readiness and measurement models. We developed a model to measure the readiness of organizations for e-learning. We have applied it on KBC bank to measure the readiness of KBC-ICT department for e-learning.
\end{abstract}

Index Terms-E-learning, Readiness, E-learning readiness, E-Readiness Indicators, Measuring Model.

\section{E-LEARNING BENEFITS AND BARRIERS}

Online innovative ICT support tools can assist the development of practical skills. Online demonstrations of practices will assist trainees by preparing them for their first experience in training [7].

There is no doubt that e-learning can replace part of the traditional classroom training. But organizations have to be ready to adopt e-learning to benefit from it and to prevent cost overrun and failure. Successful adopting of e-learning requires that the organization's e-learning readiness has to be measured first.

The quality of the e-learning activities is enhancing because the level of communication and interaction between learners and with trainers has been improved by using innovative ICT support tools, which enhance the effectiveness of the learning process and the learning outcomes [9].

E-learning can offer benefits to the organization. [8]. It reduces the costs related with traveling. It provides 24/7 services and global access via internet. The e-learning course can afterwards still be available as supporting knowledge source. A big group of employees can be trained in a time frame. E-learning enables communities and employees to share knowledge, and discuss about which will result in moving towards a learning organization.

On the other hand, while there are valuable benefits in adopting e-learning, organizations are facing significant barriers which should be taken into consideration to eliminate its impact on e-learning process to reach a successful learning outcomes [10].

Often as barriers you can hear change resistance, difficulty and expensive development of e-learning courses and lack of time to follow the courses. Another problem can be the lack of availability of the appropriate hardware and other infrastructure for learning. And train the trainers is stillunsolved challenge.

To guarantee the successful implementation of elearning, to realize the benefits, and to overcome the barriers, an organization must be ready for e-learning by measuring its readiness and improve the weak points.

\section{E-LEARNing REAdiness MEASUREMENT ModELS}

In the literature we can find a variety of e-learning readiness and measurement models, some of them are listed below.

\section{A. Bekim Fetaji and Majlinda Fetaji Model:}

This model consists of 7 e-learning indicators to measure organizational e-learning readiness: Learners' education and cultural background, learners' Computing skills, learners' learning preferences, the quality of e-learning content, viable learning environment and its e-learning logistics, learners' motivation, students' attitudes toward technology [1].

\section{B. STOPE Model:}

STOPE model is an illustrative representation of the ereadiness assessment. STOPE has 5 main categories: Leadership, Technology, Organization, People, and Environment. In addition, each of these categories is divided into a number of sub-categories [5].

\section{Chapnick Model:}

Chapnick has developed an instrument for assessing organizational readiness for e-learning. She lists 66 factors in question format and grouped them into 8 categories: Psychological, sociological, environmental, human resources, financial readiness, technological skill (aptitude), equipment, content readiness. For each stakeholder group, a different combination of factors is examined. However, this model provides a simplified way of determining whether e-learning can be implemented successfully, and if so, what strengths are on your side. If not, what obstacles must be overcome and addressed?[3]

\section{Li-An Ho model:}

Li-An Ho presented a model consisting of 4 main categories that should be measured to assess organizational readiness for e-learning; which are: e-learning system quality, technology readiness, learning behavior, and learning outcome [6].

\section{E. Haney Model:}

Haney suggests that organizations should ask themselves 70 questions for assessing their readiness for elearning. She classifies these questions into 7 categories: 
Human resources, learning management system, learners, content, information technology, finance, and vendor [4].

\section{F. Chai Lee et al Model:}

Chai Lee et al. have developed the following factors that should be measured and evaluated to successfully adopt e-learning: Organizational factors(Technical infrastructure, Management support for training, and Clearly defined change leadership strategy), General factors(Adult learning principles, Clearly defined learning outcomes, Pretest option, Clearly defined learning pathways, and Assessment), and Cognitive factors(Access to useful help facilities, User control of screen information, Simple user interface, Access to presentation of complex information, Appropriate use of multimedia, Avoidance of redundant information) [2].

\section{Our E-Learning Readiness Measurement Model}

Based on the literature and our research, we developed a model to measure the readiness of organizations for elearning (Table I), the model consists of 5 main criteria; for each criteria a set of sub-criteria have been developed.

TABLE I.

E-LEARNING READINESS MEASUREMENT MODEL

\begin{tabular}{|c|c|}
\hline \multicolumn{2}{|r|}{ Criteria 1: Facilities and infrastructure for e-learning } \\
\hline 1 & User ICT infrastructure \\
\hline 2 & Internet connectivity \\
\hline 3 & Learning management system \\
\hline 4 & E-learning room \\
\hline \multicolumn{2}{|r|}{ Criteria 2: Management } \\
\hline 5 & Willingness to invest in e-learning implementation \\
\hline 6 & Learning time for staff \\
\hline \multicolumn{2}{|c|}{ Criteria 3: Organization of e-learning function/ department } \\
\hline 7 & Informing about available e-learning courses \\
\hline 8 & Organization of the e-learning activity \\
\hline 9 & Preparatory training in use of computers \\
\hline 10 & Preparatory training in use of e-learning system \\
\hline \multicolumn{2}{|r|}{ Criteria 4: Learners characteristics } \\
\hline 11 & Learners have ICT skills \\
\hline 12 & Learners have internet experience \\
\hline 13 & Learners are motivated to take e-learning courses \\
\hline 14 & Learners prefer their own learning style \\
\hline \multicolumn{2}{|c|}{$\begin{array}{l}\text { In case the organization has already implemented e-learning, but } \\
\text { experiences problems on point of adoption, we have an additiona } \\
\text { set of indicators that can be measured by asking questions to the } \\
\text { staff members e-learners: }\end{array}$} \\
\hline \multicolumn{2}{|r|}{ Criteria 5: E-learning course and process } \\
\hline 15 & E-learning course content \\
\hline 16 & E-learning course presentation \\
\hline 17 & Progress in the course \\
\hline 18 & Level of personalization \\
\hline 19 & Support and help \\
\hline 20 & Evaluation of the learning results \\
\hline 21 & Tracking of the participation in the e-learning course \\
\hline
\end{tabular}

\section{CASE KBC BANK}

\section{A. KBC Group and KBC ICT Services department}

$\mathrm{KBC}$ is a Belgian bank and insurances company. KBC Group is becoming a global player in the Banking and Insurance sector. Its core markets are in Europe: Belgium (180 billion (bn) EUR), Czech Republic (36 bn EUR), Hungary (12 bn EUR), Poland (12 bn EUR), Slovakia (6 bn EUR) and Bulgaria (1 bn EUR). KBC group has about 63.000 employees and 13.000 .000 customers.

Training of their employees is one of the important challenges they have to deal with. Training@KBC is responsible for training staff of the Group. KBC ICT services are an international department responsible for the ICT systems and services in the Group. KBC ICT services have about 3.400 employees from which about 1900 in Belgium. KBC ICT Training is as a subdepartment of Training @KBC. the central contact point with respect to and responsible for ICT training and for training of KBC ICT.

\section{B. KBC-ICT e-learning}

KBC organizes classroom training, but very often training sessions aren't filled or too many people at one time want to follow a course. Another disadvantage of training room sessions is the fact that these courses aren't just in time. For employees in Central Europe but especially for those in India, the traveling costs will be very high if the employees have to come to Belgium every time they want to follow a course.

KBC tries to overcome the shortcomings of classroom training and to solve the distance problems by implementing e-learning. Therefore KBC is walking the e-road, by making e-courses available. There are a lot of advantages for e-learning. The employees of KBC can follow them any time at any place. The people of KBC will be able to select parts of courses and concentrate on the most important topics. If there is something that needs some extra attention, it can be repeated as much as needed. Every employee will be able to study a course at his or her own pace. After following the e-courses they will be able to use it as a quick reference.

KBC develops his own tools for e-learning. They make use of deferent information elements like: eye catchers, symbols, photos, drawings, content buttons, schemes, screenshots, hyperlinks, demo's, animations, questions and tests, etc. They experienced some advantages in comparison with classroom learning, they can focus create a task oriented solutions. But it is also a very time consuming and expensive building process.

\section{KBC e-learning adoption problem}

At their e-academy, KBC offers a new set of more than two thousand eight hundred titles in ten knowledge areas. They are available twenty-four hours a day, seven days a week, at work or at home. But still not all people of KBC make use of them. The implementation of e-learning is not going the way the KBC management has hoped. KBC would like to know the reason for limited use and what they can do to convince the employees to use e-learning.

\section{D. e-learning readiness survey results}

A survey was organized in KBC ICT. 240 respondents submitted the completed questionnaire. The used questionnaire included statements about the indicators of our model. For each statement the respondents have to answer the two questions:

- Do you agree with the statement?

- Is the statement important/ relevant for you?

The overall agreement by the respondents as being the mean weighted value over all questions and all respondents is 2.74. By comparing the values of the sub-criteria with the overall mean value we can identify those aspects that need improvement (Figure 1. and Table II.). 
1

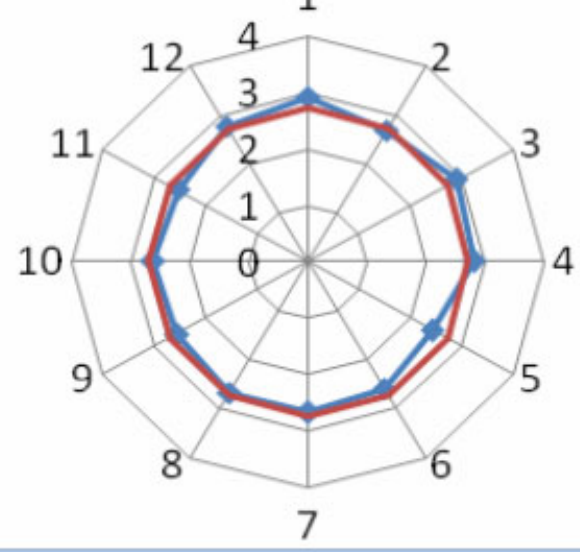

\section{$\multimap$ Weighted mean of sub-criteria Overall weighted mean $=2,74$}

Figure 1. Weighted mean value of agreement with the statements (weighted with the importance/relevance)

In Table II, we decided on the necessity of improvement of the sub-criteria. Improvement is needed if the weighted mean value is less than the overall weighted mean value 2,74.

Additionally on question level we can see the \% of respondents that do not agree with the statement and find the question topic important. The system shows which questions caused the low value of a criteria group. Focus can be on these aspects.

On question level we found the following results (Table III), being the critical questions, because a lot of respondents answered that they found the statement important (importance $=3$ or 4 ), but evaluated the realization of the statement as being bad (agreement= 1 or 2 ).

\section{E. Conclusions}

Based on the analysis of the survey data, and after reading the comments made by the respondents in free format, the following conclusions were set forward.

To make effective changes, it is important that KBC find good solutions for the critical points. It is important that the e-learning portfolio is linked with the job perception. If not, employees don't feel that they are gaining knowledge and this is not stimulating.

$\mathrm{KBC}$ can achieve this linking by first looking at the jobs and focus on what the jobs really need. If the portfolio is based on what the employees need the most, instead of some basic skill improvement packages, the employees will be more willing to take these courses. So get them aboard and let them decide what the content of the courses is. In that way you create a course-on demand system.

Also it is important that the employees are encouraged to learn through e-learning courses. A simple way to do this is: providing only e-courses and no normal study material for some topics. By doing so, the employees are 'forced' to learn through the e-learning courses.

Another, not so compelling way to achieve participation is by encouraging the employees with bonuses. These bonuses can be: money, gifts, diners, etc. Or the management can organize a company-competition about the e-learning courses scores.
TABLE II.

WEIGHTED MEAN VALUE FOR EACH SUB-CRITERIA

\begin{tabular}{|c|c|c|}
\hline Sub-criteria & Value & Status \\
\hline $\begin{array}{l}\text { 1. The organization of E- } \\
\text { learning courses }\end{array}$ & 2,93 & $\begin{array}{c}\text { Improvement less or not } \\
\text { needed }\end{array}$ \\
\hline $\begin{array}{l}\text { 2. Management is motivating } \\
\text { the employees to take e- } \\
\text { learning courses }\end{array}$ & 2,67 & Improvement needed \\
\hline $\begin{array}{l}\text { 3. Management is enabling e- } \\
\text { learning }\end{array}$ & 2,89 & $\begin{array}{c}\text { Improvement less or not } \\
\text { needed }\end{array}$ \\
\hline 4. Learners skills & 2,98 & $\begin{array}{c}\text { Improvement less or not } \\
\text { needed }\end{array}$ \\
\hline 5. Learners attitude & 2,67 & Improvement needed \\
\hline 6. Learners environment & 2,58 & Improvement needed \\
\hline $\begin{array}{l}\text { 7. User infrastructure for e- } \\
\text { learning }\end{array}$ & 2,66 & Improvement needed \\
\hline $\begin{array}{l}\text { 8. User access to e-learning } \\
\text { portal }\end{array}$ & 2,67 & Improvement needed \\
\hline $\begin{array}{l}\text { 9. Internet communication to } \\
\text { server }\end{array}$ & 2,57 & Improvement needed \\
\hline 10. Information available & 2,64 & Improvement needed \\
\hline $\begin{array}{l}\text { 11. Relevance of e-learning } \\
\text { courses of the portfolio }\end{array}$ & 2,56 & Improvement needed \\
\hline 12. Learning concept & 2,78 & $\begin{array}{l}\text { Improvement less or not } \\
\text { needed }\end{array}$ \\
\hline
\end{tabular}

TABLE III.

CRITICAL STATEMENTS AND \% OF RESPONDENTS

\begin{tabular}{|c|c|}
\hline Statements & \% of respondents \\
\hline $\begin{array}{c}\text { Can find enough e-learning courses in the } \\
\text { portfolio that play a direct role in their job } \\
\text { and that is supporting their individual work } \\
\text { plan }\end{array}$ & $41.09 \%$ \\
\hline $\begin{array}{c}\text { The company functional development plan } \\
\text { that exists in view of assuring a high } \\
\text { proficiency in the job, is linked with the e- } \\
\text { learning portfolio. }\end{array}$ & $35.0 \%$ \\
\hline $\begin{array}{c}\text { Candidate learners were good informed } \\
\text { about the procedures to be followed to take } \\
\text { an e-learning course. }\end{array}$ & $33.99 \%$ \\
\hline $\begin{array}{c}\text { Candidate learners are encouraged to learn } \\
\text { through e-learning }\end{array}$ & $33.66 \%$ \\
\hline $\begin{array}{c}\text { They can find enough e-learning courses in } \\
\text { the portfolio fitting personal interests }\end{array}$ & $31.68 \%$ \\
\hline $\begin{array}{c}\text { The company is informing its employees } \\
\text { regularly about the existence of e-learning } \\
\text { courses portfolio }\end{array}$ & $31.53 \%$ \\
\hline $\begin{array}{c}\text { The candidate learner can find easily and } \\
\text { knows the level and the study load of the } \\
\text { courses. }\end{array}$ & $28.57 \%$ \\
\hline $\begin{array}{c}\text { E-learning courses are fitting in general job } \\
\text { needs }\end{array}$ & $27.72 \%$ \\
\hline $\begin{array}{c}\text { Employees have been explained the neces- } \\
\text { sity of taking e-learning courses to become } \\
\text { more proficient in job }\end{array}$ & $25.62 \%$ \\
\hline Good technological support is organized. & \\
\hline
\end{tabular}

The e-learner has to feel that he is supported by the management. By creating a special peaceful study environment where the learner is not interrupted and by setting up a technical support line for when the learner is experiencing technical problems, not only you will improve the learning experience but also the learner can feel that the e-learning is important for the management. If it wasn't, the management wouldn't do all these efforts.

Another point for improving the experience is to make sure that the courses have good descriptions. With good 
PAPER

descriptions, the employees know how long the course is going to take and they can plan their time on the job better. Also by bundling these descriptions, the employees have a good overview of what is available in the elearning portfolio. It's all about information. If the employees don't know clear what the e-learning courses can offer them, which courses are available and how long these courses take, the employees are not willing to take the e-learning courses. So KBC-management has to make sure that this information is available and correct. By doing so it will be easier to make the employees familiar with the e-learning system.

Last but not least, KBC has to provide better training for the employees that are taking e-learning courses. KBC can write good manuals, can organize some practice seminars or by hiring some expert trainers and sending them to the local offices.

\section{CONCLUSION}

E-learning environment provides organizations with a dynamic and interactive environment, where they can interchange, construct and share the information rapidly and when needed. E-learning environment provides learners with lifelong learning, time saving, info diversity, flexible in time and space, self-regulatory learning, cost-effectiveness, less impact on family duties and life.

However, based on the literature many organizations failed in adopting e-learning due to lack of assessment and measuring their e-learning readiness. In this paper we stress the importance of measuring organization's readiness for e-learning in order to exploit the benefits of elearning.

We developed an improved e-learning readiness measurement model, in which we included the important indicators of e-readiness. We have applied it on KBC and concluded by advising $\mathrm{KBC}$ on a set of which improvement actions they have to plan in the near future.

\section{REFERENCES}

[1] BekimFetaji and MajlindaFetaji, (2009). South East European University, Tetovo, Macedonia, Electronic Journal of e-Learning Volume 7, (1 - 28).
[2] Chai Lee Goi and Poh Yen Ng (2009) E-learning in Malaysia: Success Factors in Implementing E-learning Program, Curtin University of Technology, International Journal of Teaching and Learning in Higher Education 2009, Volume 20, Number 2, 237246, http://www.isetl.org/ijtlhe/ ISSN 1812-9129.

[3] Chapnick, S. (2000) Are you ready for e-learning? Learning Circuits: ASTD's Online Magazine All About ELearning.

[4] Haney, D. (2002) Assessing organizational readiness for elearning: 70 questions to ask, Performance Improvement, 41 (4), 8-13. http://dx.doi.org/10.1002/pfi.4140410404

[5] Khalid Al-Osaimi, AbdulmohsenAlheraish and Saad Haj Bakry (2007), STOPE-based approach for e-readiness assessment case studies, Department of Electrical Engineering, King Saud University, Riyad, Saudi Arabia, INTERNATIONAL JOURNAL OF NETWORK MANAGEMENT Int. J. Network Mgmt 2008; 18 . 65-75 Published online 5 June 2007 in Wiley InterScience (http://www.interscience.wiley.com) http://dx.doi.org/10.1002/n em.657.

[6] Li-An Ho, (2009) The antecedents of e-learning outcome: An examination of system quality, technology readiness and learning behavior, Department of Educational Technology, Tamkang University, 151, Yin-Chuan Road, Tamsui, Taipei Hsien 251, Taiwan, R.O.C. Adolescence. 01/2009; 44(175):581-599.

[7] Oliver Jones, Helen Saunders, Gary Mires (2010). The E-learning revolution in obstetrics and gynaecology, Best Practice \& Research Clinical Obstetrics and Gynaecology 24 (2010) 731-746. http://dx.doi.org/10.1016/j.bpobgyn.2010.04.009

[8] RubaJabri, 2009. Master thesis, The integration of knowledge management and e-learning to provide enhanced learning solutions in the workplace. Hasselt University, 2009.

[9] SCHREURS, Jeanne; GELAN, Anouk\& SAMMOUR, George (2009) e-Learning readiness in organisations. Case healthcare. International Journal of Advanced Corporate Learning, 2(2). p. 3439. [cat: A1].

[10] Sue Childs, Elizabeth Blenkinsopp, Amanda Hall, and Graham Walton. (2005) Effective e-learning for health professionals and students-barriers and their solutions. A systematic review of the literature - findings from the HeXL project, Health Information \& Libraries Journal, Volume 22, Issue Supplement s2, pages 20-32, December 2005.

\section{AUTHORS}

Jeanne Schreurs and Ahmad Al-Huneidi are with Hasselt University, Diepenbeek, Belgium.

Received 28 november 2011. Published as resubmitted by the authors 27 February 2012. 